November 2003

\title{
Real exchange rates, current accounts and the net foreign asset
}

\author{
position $^{* \dagger}$
}

\begin{abstract}
This paper analyses the relationship between the current account (and by implication the gross capital account) and the real exchange rate. Using a stochastic new open economy macroeconomics model with incomplete financial markets and local currency pricing, we find that this model can generate both positive as well as negative cross correlations between the real exchange rate and the current account. The implication is that gross capital inflows can be associated with both real exchange rate appreciations as well as depreciations. We find that a key determinant of the dynamics of the current account is the initial net foreign asset position the countries. Depending on whether the home economy is a creditor or a debtor in the steady state, a shock that causes the real exchange rate to depreciate may either result in an improvement or a deterioration in the current account.
\end{abstract}

Christoph Thoenissen

${ }^{*}$ I thank Rebecca Driver, Peter Sinclair and participants at a CCBS workshop on international capital movements for insightful comments. The usual disclaimer applies.

${ }^{\dagger}$ Correspondence: Department of Economics, University of St Andrews, St Andrews, Fife, KY16 9AL, Scotland. email: ct30@st-andrews.ac.uk 


\section{Introduction}

What is the relationship between a country's current account and its real exchange rate? Is an exchange rate appreciation positively correlated with a current account deficit? Much discussion of exchange rate movements in recent years, especially amongst policy makers and market commentators, has linked exchange rate appreciations with capital inflows or current account deficits. ${ }^{1}$ The implication is that capital inflows used to finance a country's current account deficit raise the demand for assets denominated in that country's currency, causing the domestic currency to appreciate. An example of this kind of reasoning amongst policy makers is given by the following quote:

'The bilateral [exchange] rates that are frequently quoted in fact tell us very little about sterling: they are essentially a reflection of the persistent general strength of the dollar on the one hand and the persistent general weakness of the euro on the other, resulting from [emphasis added] sustained capital inflows to the United States in large part from the Eurozone. ${ }^{2}$

This paper examines the theoretical link between the real exchange rate and the current account using a dynamic two-country stochastic New Open Economy Macroeconomics model. The two key variables of interest in this analysis, the real exchange rate and the current account, are modelled by assuming local currency pricing by firms and the absence of a complete set of state-contingent claims in financial markets, respectively. Modelling

\footnotetext{
${ }^{1}$ See Bailey, Millard and Wells (2001) for a policy oriented perspective on this issue.

${ }^{2}$ Speech by Sir Edward George, Governor of the Bank of England, delivered at the Lord Mayor's Dinner for Bankers and Merchants of the City of London, 20 June 2001.
} 
both the real exchange rate and the current account in this kind of framework is relatively new. A notable recent example is Bergin (2002), whose focus is however different from ours.

When firms are able to set prices in local currency, as opposed to their domestic currency, the law of one price need not hold at all times. This failure of the law of one price leads to deviations from purchasing power parity and drives the dynamics of the real exchange rate in our analysis. Engel (1999) shows that for the United States real exchange rate, deviations from the law of one price of traded goods are the most important source of real exchange rate variability.

When financial markets are incomplete, in the absence of a complete set of state-contingent claims, the current account plays a major role in the transmission of shocks between countries. A shock that results in a current account surplus redistributes wealth from the country experiencing a current account deficit to the country experiencing a current account surplus. This redistribution of assets is called a wealth effect.

When using standard linear techniques to solve this kind of model, the presence of wealth effects proves to be problematic. Models such as ours are linarised around a well defined and stationary steady state, such that the second moments of the model are based on small deviations from this steady state. Because wealth effects redistribute assets they also affect the steady state of the model, causing it to change in respond to temporary shocks. In other words, the steady state can become non-stationary. One simple way to overcome this non-stationarity problem has been put forward by Benigno, P. (2001), who assumes that domestic holdings of foreign bonds are subject to transactions costs, which are increasing in the difference between a country's actual and steady-state net foreign asset positions. The further away a country is from its steady-state net foreign asset position, the more expensive 
it becomes to take positions in the foreign bond market, thus ensuring that in long-run the country returns to its initial net foreign asset position.

The attraction of this approach is that it does not require the steady-state net foreign asset position to be zero, which accords well with empirical evidence. ${ }^{3}$ A steady-state net foreign asset position different from zero affects the dynamics of the current account in an important way. A change in the exchange rate will have a different effect on the current account if country is a net creditor than if it is a net debtor. For example, if the a country is a net creditor, a depreciation of the of the home currency will increase the value of its foreign-currency denominated assets, in terms of domestic currency. Other things remaining equal, this will improve the country's current balance. If on the other hand, the country is a net debtor, a depreciation will increase the value of its liabilities, worsening the current balance.

We show that in our model, the size as well as sign of the cross-correlation between the real exchange rate and the current account depends on (a) the net foreign asset position, (b) the type of shock, and (c) a set of key parameters.

These results differ from those of the previous literature. Bailey, Millard and Wells (2001) focus on the same set of variables, but do so using a deterministic, two-period, two-good endowment model as presented in Obstfeld and Rogoff (1996, chapter 1). In their case, the real exchange rate deviates from purchasing power parity because of changes in the relative price of non-traded goods. Given the structure of their model, they find that a real appreciation linked to a productivity improvement in the traded sector always implies a current account deficit, thus implying a positive cross-correlation.

\footnotetext{
${ }^{3}$ See Lane and Milesi-Ferretti (2001) for evidence on net foreign asset positions across countries.
} 
The remainder of this paper is structured as follows: Section 2 outlines the structure of our model. Section 3 derives the linearised current account equation. Section 4 draws out the intuition for the relationship between the current account and the real exchange rate by making a set of simplifying parameter restrictions. Sections 5 and 6 relax these restrictions and analyse the cross-correlation between the real exchange rate and the current account for a more general calibration. Section 7 highlights some of the caveats of our approach and concludes.

\section{Structure of the model}

This section reviews the main building blocks of the model. To capture the dynamics of the current account, we set up a stochastic new Keynesian two-country general equilibrium model with incomplete financial markets. In modelling our economy with incomplete financial markets, we follow Benigno, P. (2001). Our main departure from Benigno, P. (2001) is that we allow for deviations of the real exchange rate from purchasing power parity (PPP) by assuming that firms display local-currency pricing behaviour. ${ }^{4}$

The key building blocks of our model are the following: Households make optimal choices between consumption and leisure and receive utility from the holding of real money balances. Each household is also a monopolistic producer who sets a profit maximising price. In their maximisation exercise, households face a budget constraint. The structure of the asset market provides domestic agents with limited possibilities to pool consumption risk with foreign agents by holding domestic as well as foreign-currency denominated risk-free bonds.

\footnotetext{
${ }^{4}$ Purchasing power parity holds in Benigno (2001) due to the assumptions that (a) all goods are traded, (b) preferences for home and foreign-produced traded goods are the same in both economies and (c) exports set prices in their producer currency, implying full pass-through from exchange rate changes to consumer prices.
} 
Finally, the model is closed by modelling monetary policy through interest rate feed back rules. The remainder of this section sets out these building blocks in some detail.

\subsection{Household preferences}

We consider a two-country economy where both 'Home' and 'Foreign' are explicitly modelled. The home economy produces a continuum of differentiated tradable goods indexed on the interval $[0, n]$, where $n$ is the relative measure of country size. The foreign economy's goods are indexed on the interval $(n, 1]$. In each country, there is a continuum of economic agents, with population size normalised to the range of domestically produced goods. ${ }^{5}$ Consumers are infinitely lived, and behave according to the permanent income hypothesis. Each consumer consumes two types of goods: a domestically-produced good and a foreign-produced good. All goods are tradeable.

Each individual $j$ maximises the following utility function which is separable in its three arguments: where $U($.$) and N($.$) represent flows of utility from consumption and real money$ balances respectively and $V($.$) flows of dis-utility from supplying labour, { }^{6}$

$$
U_{t}^{j}=\mathrm{E}_{t} \sum_{s=t}^{\infty}(\beta)^{s-t}\left[U\left(C_{s}^{j}, \xi_{C, s}\right)+N\left(\frac{M_{s}^{j}}{P_{s}}\right)-V\left(L_{s}^{j}\right)\right]
$$

where $\xi_{C}$ is a shock to preferences towards consumption, and $C$ is a consumption index defined over home and foreign-produced goods:

$$
C=\left(n^{1 / \theta} C_{H}^{\frac{\theta-1}{\theta}}+(1-n)^{1 / \theta} C_{F}^{\frac{\theta-1}{\theta}}\right)^{\frac{\theta}{\theta-1}}
$$

\footnotetext{
${ }^{5}$ Home agents lie on the interval $[0, n]$, while foreign agents lie on $(n, 1]$.

6 We assume that $U$ is increasing and concave in $C_{t}, N$ is increasing and concave in $\frac{M}{P}$, and $V$ is increasing and convex in $L$. $\mathrm{E}_{t}$ denotes the expectation conditional on information at time $t$, while $\beta$ is the intertemporal discount factor $(0<\beta<1)$.
} 
where $n$ represents the relative weight that a Home individual puts on domestically-produced goods, as well as the relative country size of the home economy. Money is deflated by a consumption-based price index that corresponds to the above specifications of preferences:

$$
P=\left(n P_{H}^{1-\theta}+(1-n) P_{F}^{1-\theta}\right)^{\frac{1}{1-\theta}}
$$

where $\theta$ is the intratemporal elasticity of substitution between home and foreign-produced goods. Foreign individuals have analogous tastes towards domestic and imported goods.

Next, we define the following consumption sub-indices:

$$
C^{h}=\left[\left(\frac{1}{n}\right)^{\frac{1}{\sigma}} \int_{0}^{n} c(z)^{\frac{\sigma-1}{\sigma}} d z\right]^{\frac{\sigma}{\sigma-1}}, \quad C^{f}=\left[\left(\frac{1}{1-n}\right)^{\frac{1}{\sigma}} \int_{n}^{1} c(z)^{\frac{\sigma-1}{\sigma}} d z\right]^{\frac{\sigma}{\sigma-1}}
$$

where $h$ and $f$ denote the set of domestic and foreign production. Specifically Home produces a good, which we refer to as $H$, for the home market, and as $H^{*}$ for the export market. Thus, $h=H, H^{*}$, analogously $f=F, F^{*}$ where $\sigma>1$ is the elasticity of substitution for individual goods produced in the two countries. If we denote with $p(j)$ and $p^{*}\left(j^{*}\right)$ the individual price of the single differentiated good in domestic and foreign currency respectively, then it can be shown that domestic and foreign demand for the same good are given respectively by:

$$
c_{H}(j)=\frac{1}{n}\left(\frac{p(j)}{P_{H}}\right)^{-\sigma} C_{H}, \quad c_{H}^{*}(j)=\frac{1}{n}\left(\frac{p^{*}(j)}{P_{H}^{*}}\right)^{-\sigma} C_{H}^{*}
$$

where $P_{H}$ and $P_{H}^{*}$ are the price indices corresponding to the consumption subindices (4) for $h=H, H^{*}$.

\subsection{The asset market and budget constraint}

The budget constraint and asset market structure follow directly from Benigno, P. (2001), and needs only a limited exposition here. We assume that domestic agents can allocate 
their wealth between domestic money and home and foreign-currency denominated bonds. Both bonds are risk-free and mature after one period. Foreign agents allocate their wealth between foreign money and the foreign-currency denominated bond.

Formally the Home households' budget constraint is given by:

$$
\begin{gathered}
P_{t} C_{t}^{j}+M_{t}^{j}-M_{t-1}^{j}+\frac{B_{H, t}^{j}}{\left(1+i_{t}\right)}+\frac{S_{t} B_{F, t}^{j}}{\left(1+i_{t}^{*}\right) \Theta\left(\frac{S_{t} B_{F, t}}{P_{t}}\right)} \leq B_{H, t-1}^{i} \\
+S_{t} B_{F, t-1}^{j}+G_{t}^{j}+W_{t}^{j} L_{t}^{j}+\frac{\int_{0}^{n} \Pi_{t}^{j} d j}{n}
\end{gathered}
$$

The household $j$ 's risk-free one period bond denominated in units of domestic currency, $B_{H, t}^{i}$, yields a nominal rate of return of $i_{t}$. Home-currency denominated bonds are in zero net supply. The price of the foreign-currency denominated bond, $B_{F, t}^{j}$ held by household $j$ is proportional to the gross nominal rate of return of the bond, $1+i^{*}$. The factor of proportionality is the function $\Theta($.$) which depends on the real holdings of foreign-currency$ denominated assets of the entire economy. Hence individual agents take the function $\Theta($. as given when choosing their optimal level of foreign-currency denominated bond holdings. Benigno (2001) derives a set of restrictions on the function $\Theta($.$) that ensure the stationarity$ of the steady state of the model which allows us to log-linearise the model around a well defined steady state. Specifically, the function $\Theta($.$) captures a cost faced by domestic agents$ of taking a position in the foreign asset market. The cost is designed such that when the economy-wide real holdings of foreign-currency denominated bonds are above (below) the steady state level, $\bar{b}$, individual agents receive less (more) than the gross rate of return. The factor of proportionality is only equal to unity when economy-wide asset holdings are at their steady-state level. This setup ensures that in the steady state, when the gross rates of return on domestic and foreign bonds are equal, agents on aggregate hold only the 
exogenously determined steady state level of foreign currency denominated bonds. ${ }^{7} \quad M_{t}^{j}$ are the individual's holdings of money and $W_{t}^{j} L_{t}^{j}$ is the wage income received by individual $j$. The profits generated by domestic firms, $\int_{0}^{n} \Pi_{t}^{j} d j$, are distributed equally among home agents.

The fiscal authority in the home country rebates seigniorage revenues to households in the form of transfers, $G_{t}^{j}$.

$$
\int_{0}^{n}\left[M_{t}^{j}-M_{t-1}^{j}\right] d j=\int_{0}^{n} G_{t}^{j} d j
$$

To determine the resource constraint for the Home economy, we need to consolidate the public and private sectors. The public sector is described by the government budget constraint (7) and the behaviour of the private sector is described by aggregating the individual budget constraints (6) over all agents residing in the home economy. In our model the difference between total income and domestic consumption is defined as the current account:

$$
\frac{S_{t} B_{F, t}}{P_{t}\left(1+i_{t}^{*}\right) \Theta\left(\frac{S_{t} B_{F, t}}{P_{t}}\right)}=\frac{S_{t} B_{F, t-1}}{P_{t}}+\frac{P_{t} Y^{d}}{P_{t}}+\frac{S_{t} P_{t}^{*} Y_{t}^{d^{*}}}{P_{t}}-C_{t}
$$

which in our analysis is also the negative of the gross capital account.

By assuming that all households have the same initial level of assets and receive an equal share of the profits of all firms,we ensure that all households face the same budget constraint. Households choose their optimal path of consumption and bond holdings by maximising intertemporal utility, (1) with respect to the budget constraint (6). This yields two Euler equations for domestic agents: one describing the optimal holding of home bonds,

\footnotetext{
7 In this model, we simply postulate a given level of net foreign asstes relative to consumption. In an overlapping generations model, the equilibrium net foreign asset position is determined by the life cycle characteristics of agents.
} 
the other the optimal holdings of foreign bonds. Agents in the foreign economy face a similar budget constraint which differs from that faced by home agents in two respects, first they hold only their own-currency denominated bonds and second, they receive the profits from the cost of intermediation that home agents face when taking positions in the foreign asset market.

\subsection{The consumer's problem}

Households' equilibrium conditions are described by the following equations:

$$
\begin{gathered}
U_{C}\left(C_{t}, \xi_{C, t}\right)=\left(1+i_{t}\right) \beta E_{t}\left[U_{C}\left(C_{t+1}, \xi_{C, t+1}\right) \frac{P_{t}}{P_{t+1}}\right] \\
U_{C}\left(C_{t}, \xi_{C, t}\right)=\left(1+i_{t}^{*}\right) \Theta\left(\frac{S_{t} B_{F, t}}{P_{t}}\right) \beta E_{t}\left[U_{C}\left(C_{t+1}, \xi_{C, t+1}\right) \frac{S_{t+1} P_{t}}{S_{t} P_{t+1}}\right] .
\end{gathered}
$$

Equations (9) and (10) represents the home consumer's optimal holdings of home and foreigncurrency denominated bonds, respectively. Note that the rate of return on foreign currency denominated bonds depends on the foreign gross rate of interest, $\left(1+i_{t}^{*}\right)$ and on a factor of proportionality, $\Theta\left(\frac{S_{t} B_{F, t}}{P_{t}}\right)$, which is equal to unity only when the home country's holdings of net foreign assets are at their steady-state level.

The foreign consumer's optimal choice of bond holdings yields the following condition:

$$
U_{C}\left(C_{t}^{*}, \xi_{C, t}^{*}\right)=\left(1+i_{t}^{*}\right) \beta E_{t}\left[U_{C}\left(C_{t+1}^{*}, \xi_{C, t+1}^{*}\right) \frac{P_{t}^{*}}{P_{t+1}^{*}}\right]
$$

\subsection{Firms' price-setting behaviour}

Each firm is a monopolistic producer of a single differentiated good. Firms use labour as their primary input. The production function is subject to shocks to the level of total factor 
productivity (TFP), A. Under price flexibility a monopolistic producer sets prices as a mark-up over unity cost. An important dynamic element in our model consists of modelling the price-setting behaviour according to a partial adjustment rule à la Calvo (1983). At each point in time, each firm can change its price with probability $1-\alpha$. This probability is independent of the time elapsed since the last price change, so the average time over which a price is fixed is given by $\frac{1}{1-\alpha}$.

The firms in our model set price in the local currency of their market. This assumption requires a degree of market segmentation, which prevents goods market arbitrage from equalising the price of traded goods, when expressed in a common currency. This opens up an important channel of deviation of the real exchange rate from purchasing power parity.

If we denote with $p_{t}^{H}(j)$ the price chosen at time $t$ and with $\widetilde{y}_{t, t+k}^{H d}(j)$ the demand for the individual good $H$ at home, produced by producer $j$ at time $t+k$, conditional on keeping the price fixed at the level chosen at time $t$, the first-order condition for the domestic goods producer is given by:

$$
\mathrm{E}_{t}\left\{\sum_{k=0}^{\infty}(\alpha \beta)^{k} U_{C}\left(C_{t+k}\right) \frac{P_{H t+k}}{P_{t+k}} \widetilde{y}_{t, t+k}^{H d}(j)\left[\frac{\widetilde{p}_{t}^{H}(j)}{P_{H, t+k}}-\left(\frac{\sigma}{\sigma-1}\right) \frac{W_{t+k}^{i}}{P_{H, t+k} A_{H, t+k}}\right]\right\}=0
$$

Domestic producers selling goods in the foreign market perform similar optimisations:

$$
\mathrm{E}_{t}\left\{\sum_{k=0}^{\infty}(\alpha \beta)^{k} U_{C}\left(C_{t+k}\right) \frac{P_{H t+k}}{P_{t+k}} \widetilde{y}_{t, t+k}^{H d^{*}}(j)\left[\begin{array}{c}
\frac{\widetilde{p}_{t}^{H^{*}}(j)}{P_{H^{*}, t+k}} \frac{P_{H^{*}, t+k} S_{t+k}}{P_{H, t+k}}- \\
\left(\frac{\sigma}{\sigma-1}\right) \frac{W_{t+k}^{i}}{P_{H, t+k} A_{H, t+k}}
\end{array}\right]\right\}=0
$$

where $S_{t+k}$ is the nominal exchange rate defined as the domestic price of a unit of foreign currency at time $t+k$ and $\widetilde{y}_{t, t+k}^{H d^{*}}(j)$ is the demand for the individual good $H$ abroad, produced 
by producer $j$ at time $t+k .^{8}$

\subsection{The real exchange rate}

In this model, we allow for only one channel of deviation from purchasing power parity. ${ }^{9}$

Due to local currency pricing, the real exchange rate in our model deviates from PPP via deviations from the law-of-one-price. We define the consumption based real exchange rate as:

$$
R S=\frac{S P^{*}}{P}
$$

where $P$ and $P^{*}$ are the home and foreign price levels and $S$ is the nominal exchange rate, defined as the home-currency price of a unit of foreign currency. Hence, an increase (decrease) in the real exchange rate represents a real depreciation (appreciation).

\subsection{Monetary Policy}

In this model, as in many other recent contributions, we make the simplifying assumption that monetary policy is characterised in terms of an interest rate feedback rule. Each monetary authority sets the nominal interest rate according to current economic conditions. In particular, we assume that the monetary authorities in both countries follow a Taylor-type rule with interest rate smoothing. Under these rules, monetary policy reacts to current inflation and to the output gap. In log-linearised form, the monetary policy reaction functions can be expressed as follows:

\footnotetext{
${ }^{8}$ See Benigno, G. (2001) for a derivation and discussion of local-currency-pricing Phillips curves.

${ }^{9}$ See Benigno, G and Thoenissen, C (2003 a) for a similar model which analyses three separate channels of deviation from PPP.
} 


$$
\begin{gathered}
i_{t}=\lambda_{i} i_{t-1}+\left(1-\lambda_{i}\right) \lambda_{\pi} \pi_{t}+\left(1-\lambda_{i}\right) \lambda_{y}\left(y_{t}-\bar{y}_{t}\right)+\varepsilon_{t}^{M} \\
i_{t}^{*}=\lambda_{i}^{*} i_{t-1}^{*}+\left(1-\lambda_{i}^{*}\right) \lambda_{\pi}^{*} \pi_{t}^{*}+\left(1-\lambda_{i}^{*}\right) \lambda_{y}^{*}\left(y_{t}^{*}-\bar{y}_{t}^{*}\right)+\varepsilon_{t}^{M^{*}}
\end{gathered}
$$

where CPI inflation, $\pi$ and the deviation of sticky-price output form its flexible-price level, $(y-\bar{y})$ are the set of target variables for the home (foreign) country, given the information set at time $t . \varepsilon_{t}^{M}$ and $\varepsilon_{t}^{M^{*}}$ are monetary policy shocks that in this setting represent deviation from the systematic component of the interest rate rule.

\subsection{Log-linear equilibrium}

We log-linearise the equations of the model around a well defined and stationary steady state. The linearised model is solved using a technique put forward by King and Watson (1998). The solved model is used to extract impulse response functions and for stochastic simulations subject to total factor productivity, monetary policy and preferences shocks.

\section{The linearised current account}

The structure of the asset market ensures that the steady state is well defined for our incomplete markets model. By introducing a cost of intermediation in the foreign bond market, we ensure that the level of foreign bond holdings relative to consumption is stationary. It is this feature which allows us to linearise around a well defined steady state.

The most important equation for our analysis is the log-linarised current account equa- 
tion:

$$
\begin{aligned}
\beta(1+\bar{a} \delta) \hat{b}_{t}= & \bar{a}\left(\beta i_{t}^{*}-\pi_{t}+\Delta s_{t}\right)+\hat{b}_{t-1} \\
& +(1-n) \widehat{R S}_{t}-(1-n)\left[\widehat{C}-\widehat{C}_{t}^{*}\right] \\
& +(1-n)(\theta-1)\left[n \widehat{T}_{t}+(1-n) \widehat{T}_{t}^{*}\right] \\
& +\bar{a}(\beta-1)\left[\widehat{C}_{t}^{*}+\widehat{R S}_{t}+(1-n)(\theta-1) \widehat{T}_{t}^{*}\right]
\end{aligned}
$$

where $\hat{b}_{t}=\left(\frac{S_{t} B_{F, t}}{P_{t}}-\bar{b}\right) \frac{1}{\bar{C}}$ is the deviation of real holdings of foreign-currency denominated bonds from their steady state level, relative to the domestic steady state level of consumption. $\delta \equiv-\Theta^{\prime}(\bar{b}) \bar{C}$ is the cost of intermediation in the foreign bond market and measures the spread of the domestic rate (in the foreign currency market) over the foreign rate. $\bar{a}$ is the steady state level of foreign bond holding divided by the steady state level of consumption: $\frac{\bar{b}}{\bar{C}}$. Any variable $\widehat{X}_{t}$ denotes the $\log$ deviation of $X_{t}$ from its steady state level.

In the general specification (16), the current account depends on the deviation of the return of the foreign asset, $\left(\beta i^{*}-\pi_{t}+\Delta s_{t}\right)$, on the deviation in the terms of trade, $\widehat{T}$ at home and abroad (where $T=\frac{P_{F}}{P_{H}}$ and $T^{*}=\frac{P_{F}^{*}}{P_{H}^{*}}$ ), on the deviation of consumption at home and abroad, $\widehat{C}, \widehat{C}^{*}$ and on the deviation of the real exchange rate, $\widehat{R S}$, all from their steady-state levels. Having set out the current account equation in its general form, we now consider a few simple special cases to facilitate our analysis.

\section{Some special cases}

Before we proceed to analyse the cross-correlation between the current account and the real exchange rate generated by our calibrated model economy, this section looks at some special cases, which highlight the role of some key parameters. Specifically, we examine the role of 
the intertemporal elasticity of substitution, and the intratemporal elasticity of substitution between imports and exports, and the net foreign asset position.

\subsection{Baseline calibration}

We start with a perfectly symmetric calibration, where preferences over goods (2), are CobbDouglas, ie. $\theta=1$ and the steady-state asset position, $\bar{a}$, is zero. Applying these parameter restrictions to (16) yields the following simplified expression for the current account:

$$
\beta \hat{b}_{t}=\hat{b}_{t-1}+(1-n) \widehat{R S}_{t}-(1-n)\left[\widehat{C}_{t}-\widehat{C}_{t}^{*}\right]
$$

In this simple case, the dynamics of the current account depend on those of the real exchange rate and on those of relative consumption in the two economies. Ceteris paribus a depreciation of the real exchange rate (a positive $\widehat{R S}$ ) results in a positive current account balance ( $\hat{b}$ is positive). A rise in relative consumption, on the other hand, worsens the current account balance.

The cross-correlation between the current account and the real exchange rate thus depends on the relationship between the real exchange rate and relative consumption. The theoretical determinants of this cross-correlation are analysed in Benigno and Thoenissen (2003 b). They find that the data show no consistent pattern for this cross-correlation, which, depending on the sample of countries chosen, can be either positive or negative, with a mean close to zero. A key theoretical determinant of the relationship between the real exchange rate and the current account in our model is the intertemporal elasticity of substitution. Throughout this paper, we assume that preferences, $U$, are of the constant relative risk aversion (CRRA) type, such that $-U_{c c}(C) \bar{C} / U_{c}(C)$ is equal to the inverse of 
the intertemporal elasticity of substitution, $\rho$. Figure 1 shows the impulse responses of the real exchange rate and the current account following a one-off one standard deviation increase in domestic total factor productivity. Throughout, the real exchange rate is shown to depreciate following an increase in domestic total factor productivity. As the supply of home-produced goods increases, their relative price must fall to clear the market. Because of local currency pricing behaviour of firms changes in the nominal exchange rate are not fully passed through into prices, causing the real exchange rate to depreciate. ${ }^{10}$ The first column replicates this simulation for the symmetric baseline calibration for various values of $\rho$. When the intertemporal elasticity of substitution is equal to unity, the current account remains unchanged following a supply side shock. This is because under supply side shocks, relative consumption and the real exchange rate are perfectly correlated for this set of parameters. ${ }^{11}$ As $\rho$ increases and the intertemporal elasticity of substitution declines, agents are less willing to smooth consumption across states of nature and time. As a result, relative consumption moves by less then the consumption-based real exchange rate, so that the current account improves following a increase in TFP. The cross-correlation between the current account and the real exchange rate is thus positive. For values of $\rho$ below unity, when the intertemporal elasticity of substitution is greater than one, relative consumption is more volatile than the real exchange rate, such that a TFP improvement results a current account deficit and thus a negative cross-correlation between the real exchange rate and the current account. In this case, the current account becomes counter-cyclical.

\footnotetext{
10 See Benigno and Thoenissen (2003 a) for an analysis of the real exchange rate response to supply-side improvements in a model with local currency pricing, conumption home bias and non-traded goods.

11 See Benigno, P. (2001) and Benigno and Thoenissen (2003 b) on this.
} 


\section{[FIGURE 1 ABOUT HERE]}

The empirical evidence on the size of the $\rho$ is inconclusive. Fernandez-Corugedo and Cromb (2002) suggest values for $(1 / \rho)$ of between zero and 2 , encompassing both positive as well as negative correlations between the current account and the real exchange rate.

\subsection{The elasticity of substitution between home and foreign-produced traded goods}

Starting from our baseline calibration, this section relaxes the assumption that the elasticity of substitution between imports and exports, $\theta$ is unitary. This adds a further term to our current account equation, namely the terms of trade, $\widehat{T}$.

$$
\beta b_{t}=b_{t-1}+(1-n)(\theta-1)\left[n \widehat{T}_{t}+(1-n) \widehat{T}_{t}^{*}\right]-(1-n)\left[\widehat{C}_{t}-\widehat{C}_{t}^{*}-\widehat{R S}\right]
$$

Ceteris paribus, when the elasticity of substitution is greater than unity, $\theta>1$, such that domestic and foreign-produced goods are substitutes in consumption, there is a positive correlation between the terms of trade, defined as $\frac{P_{F}}{P_{H}}$ and $\frac{P_{F}^{*}}{P_{H}^{*}}$ and the current account. When the relative price of imported goods increases, consumers substitute away from imported towards home-produced goods which, other things remaining constant, improves the current account. When $\theta<1$, such that domestic and foreign-produced goods are complements in consumption, a depreciation of the terms of trade (a rise in $T$ ), all things remaining equal, leads to a worsening of the current account.

The second column of Figure 1 shows the response of the current account and the real exchange rate to a 1 standard-deviation shock to home TFP for various values of $\theta$. If $\theta>1$ the cross-correlation is positive, whereas if $\theta<1$ the model generates a negative 
cross-correlation.

Empirical evidence suggests values of $\theta$ of around and above unity. For instance, Backus,Kehoe and Kydland (1995) choose a value of 1.5, whereas Heathcote and Perri (2002) choose a value of 0.9 .

\subsection{Steady-state net foreign assets}

So far we have focused our analysis on cases where the steady-state level of net foreign assets is zero. In this section, we assume our baseline calibration, but let $\bar{a}$, the steady-state level of foreign-currency denominated bonds relative to steady-state consumption be different from zero.

$$
\begin{aligned}
\beta(1+\bar{a} \delta) b_{t}= & \bar{a}\left(\beta i_{t}^{*}-\pi_{t}+\Delta s_{t}\right)+b_{t-1}-(1-n)\left[\widehat{C}_{t}-\widehat{C}_{t}^{*}-\widehat{R S}_{t}\right] \\
& +\bar{a}(\beta-1)\left[\widehat{C}_{t}^{*}+\widehat{R S}_{t}\right]
\end{aligned}
$$

Letting steady-state net foreign assets differ from zero introduces additional terms to our current account equation. The first of these terms captures the effects of changes in the real rate of return on foreign-currency denominated bonds. The real return on foreign currency-denominated bonds is positively affected by the foreign policy rate, $i_{t}^{*}$, and the rate of depreciation of the nominal exchange rate, $\Delta s_{t}$. An increase in domestic inflation, on the other hand, reduces the real return from holding foreign currency denominated assets. If the domestic economy is a net creditor in the steady state, such that $\bar{a}>0$, an increase in the return on bonds improves the current account. If the domestic economy is a net debtor in the steady state, such that $\bar{a}<0$, an increase in the return payable on foreign bonds will worsen the current account. 
The third column of Figure 1 shows that the inclusion of a non-zero steady-state asset position does not qualitatively alter the dynamics of the real exchange rate, but it does change the dynamics of the current account. If the economy is net creditor, the real exchange rate and the current account initially move in the same direction. In the period following the shock, the current account moves into deficit, from which it gradually returns to equilibrium along the adjustment path. When the net foreign asset position is negative, the dynamics of the current account are reversed, while those of the real exchange rate remain largely unchanged.

For our symmetric baseline calibration, a positive (negative) $\bar{a}$ results in a positive (negative) cross-correlation between the current account and the real exchange rate.

Lane and Milesi-Ferretti (2001) provides estimates of net foreign asset positions relative to GDP for a variety of economies. Values of $\bar{a}$ (the steady-state net foreign asset position relative to home consumption) between -0.5 and 0.5 appear reasonable for OECD countries.

Having analysed the correlations between the real exchange rate and the current account under some special cases, the next section offers a more general calibration, which allows us to derive the cross-correlation between the current account and the real exchange rate generated by our model.

\section{Calibration}

Our calibration serves only as an illustration of the properties of the model and is not intended to match any particular pair of economies. We assume that Home and Foreign are two economies equal in size, $n=0.5$. For simplicity, we also assume that both economies are symmetric. We set $\beta=0.99$ which implies a steady state real interest rate of about $4 \%$ 
in a quarterly model. We follow Rotemberg and Woodford (1997) in setting the inverse of the elasticity of labour supply, $\eta=0.47$. We choose 1.5 for the inverse of the intertemporal elasticity of substitution $\rho$ which lies within the range suggested by the literature. The degree of monopolistic competition is also taken from Rotemberg and Woodford (1997), who set $\sigma=7.88$ which implies an average mark-up of some $15 \%$. We assume an elasticity of substitution between home and foreign-produced traded goods, $\theta$ of 1.5 . The average duration of price contracts in both countries is assumed to be 4 quarters, implying $\alpha=0.75$. For our monetary policy rule, we choose a standard Taylor rule with lagged inflation with the following weights: $1.5,0.5$ and 0.75 for the response to inflation, $\lambda_{\pi}$, the output gap, $\lambda_{y}$ and lagged inflation, $\lambda_{i}$, respectively. Finally, in setting the cost of intermediation in the foreign bond market, we choose $\delta=0.001$ which implies a 10 basis point spread of the domestic rate (in the foreign bond market) over the foreign rate.

We calibrate three types of shocks: shocks to total factor productivity, shocks to the preference for consumption, and interest rate shocks. The associated shock processes take on the following form:

$$
\begin{aligned}
A_{t} & =\omega_{1} A_{t-1}+u_{1, t} \\
\xi_{C, t} & =\omega_{2} \xi_{C, t-1}+u_{2, t} \\
\varepsilon^{M} & =u_{3, t}
\end{aligned}
$$

where $u_{1}, u_{2}$ and $u_{3}$ are white noise processes and $\omega_{1}$ and $\omega_{2}$ measure the persistence of shocks. In calibrating productivity shocks, we follow Chari et al (2002) such that $\omega_{1}=\omega_{1}^{*}=$ 0.95, $\operatorname{var}\left(u_{1}\right)=\operatorname{var}\left(u_{1}^{*}\right)=(0.007)^{2}$ and $\operatorname{corr}\left(u_{1}, u_{1}^{*}\right)=0.25$. For the remaining two shocks 
we assume that these are un-correlated across countries, have unit variance and that $\omega_{2}=0$.

\section{Cross-correlation between the current account and the real exchange rate}

In this section we consider the cross-correlations between the real exchange rate and the current account that are generated by the calibrated model defined as:

$$
\operatorname{Corr}(R S, C A)=\frac{\operatorname{Cov}(R S, C A)}{\sqrt{\operatorname{Var}(R S) \times \operatorname{Var}(C A)}} .
$$

We analyse this cross-correlation for two types of shocks, asymmetric or country specific shocks as well as symmetric or global shocks.

\subsection{Asymmetric shocks}

We start our analysis with asymmetric or relative shocks originating in the home economy.

Table 1 looks at TFP, interest rate as well as preference shocks for three levels of steadystate foreign-currency denominated bonds relative to steady-state consumption. A value of $\bar{a}= \pm 0.5$ corresponds to assets/debts of $50 \%$ of consumption.

Table 1: Asymmetric shocks

\begin{tabular}{llll}
\hline \hline & TFP shocks & Interest rate shocks & Preference shock \\
& $\operatorname{Corr}(R S, C A)$ & $\operatorname{Corr}(R S, C A)$ & $\operatorname{Corr}(R S, C A)$ \\
$\bar{a}=0$ & 0.855 & 0.981 & -0.601 \\
$\bar{a}=0.5$ & 0.756 & 0.698 & -0.605 \\
$\bar{a}=-0.5$ & -0.008 & -0.217 & -0.596 \\
\hline \hline
\end{tabular}

Under TFP or interest rate shocks, the real exchange rate is positively correlated with the current account in the zero net foreign asset case, as well as in the case when $\bar{a}$ is equal to 0.5 . This corresponds to the common prior that real exchange rate appreciations are positively correlated with current account deficits or gross capital account surpluses. 
However, when we assume that the home economy is a net debtor in the steady state, assuming that $\bar{a}=-0.5$ the correlation becomes negative. In this case, the direct effect on the current account coming from the return on foreign-currency denominated debt, outlined above, dominates. Under preference shocks, the correlation is negative for all analysed levels of $\bar{a}$. A positive shock to home preferences over consumption raises home consumption relative to foreign consumption and results in a current account deficit. The real exchange rate on the other hand, depreciates. A preference shock in the home country raises relative consumption and thus relative inflation. If home inflation rises above foreign inflation, the nominal exchange rate will tend to depreciate to bring relative prices back into line. Under full pass-through, the nominal exchange rate exactly offsets the inflation differential, thus leaving the real exchange rate unchanged. In this model we find that the lower the degree of pass-through, the more the nominal exchange rate will react to inflation differentials, over depreciating in response to a positive inflation differential; as a result the real exchange rate depreciates.

For all these shocks, the qualitative relationship between the real exchange rate and the shock does not change, it is the link between the shock and the current account that depends on the net foreign asset position.

\subsection{Symmetric shocks}

In this section, we analyse the cross-correlation between the real exchange rate and the current account under 'global' or symmetric shocks. Since we have chosen a symmetric calibration, where both countries are essentially identical, a global shock in a setting where the net foreign asset position, $\bar{a}$, is zero would leave both the current account balance and the 
real exchange rate unchanged. In order for either the current account or the real exchange rate to respond to a symmetric shock, we require some form of asymmetry in the model. As a result we limit our analysis to non-zero values of $\bar{a}$. Furthermore, we focus only on TFP and interest rate shocks, which are easier to interpret as global shocks. ${ }^{12}$

\begin{tabular}{lll}
\multicolumn{3}{c}{ Table 2: Symmetric shocks } \\
\hline \hline & TFP shocks & Interest rate shocks \\
& $\operatorname{Corr}(R S, C A)$ & $\operatorname{Corr}(R S, C A)$ \\
$\bar{a}=0.5$ & -0.015 & 0.548 \\
$\bar{a}=-0.5$ & -0.448 & 0.538 \\
\hline \hline
\end{tabular}

Our analysis of symmetric shocks focuses on two findings: For our model and calibration, we find, in table 2, that under symmetric shocks the sign of the cross-correlation between the real exchange rate and the current account depends on the type of shock and not on the net foreign asset position, as we saw in the previous example. TFP shocks are associated with negative cross-correlations, whereas global interest rate shocks are associated with positive cross-correlations between the real exchange rate and the current account.

Unlike under asymmetric or country specific shocks, figure 2 illustrates that the initial response of the real exchange rate following a symmetric shock depends on the steady-state net foreign asset position. Figure 2 shows that for positive (negative) net foreign asset positions, the real exchange rate depreciates (appreciates) following an increase in either global TFP or interest rates.

\section{[FIGURE 2 ABOUT HERE]}

Following a symmetric or global shock to TFP, we find that home consumption increases

12 Specifically, we analyse cases where home and foreign shocks are perfectly correlated, such that $\operatorname{corr}\left(u_{1}, u_{1}^{*}\right)=\operatorname{corr}\left(u_{3}, u_{3}^{*}\right)=1$. 
by more than foreign consumption if home is a net creditor in the steady state, i.e. $\bar{a}>0$. If home is a net debtor in the steady state, i.e. $\bar{a}<0$, home consumption rises by less than foreign consumption. The increase in relative consumption in the net creditor country has two effects. First, the current account will show a negative balance throughout the transition path. Second, relative inflation will be higher. The nominal exchange rate in our model moves in such a way as to bring relative prices at home and abroad back towards equilibrium. Thus, if home inflation exceeds foreign inflation the nominal exchange rate tends to depreciate. In the presence of local currency pricing, the nominal exchange rate will depreciate by more than the amount required to bring the real exchange rate back to equilibrium, thus leading to a depreciation of the real exchange rate. This explains both the negative cross-correlation between the real exchange rate (rises) and the current account (falls) and why the response of the real exchange rate depends on the net foreign asset position.

The behaviour of the real exchange rate following a global interest rate rise can be explained in the same way as the response to a global TFP shock. The current account dynamics, on the other hand, and thus the cross-correlation between the real exchange rate and the current account, are different. A rise in home and foreign interest rates directly increases the rate of return from holding assets in the steady state. This effect dominated the factors that move the current account in the case of an increase in TFP. If the economy is a net creditor, if $\bar{a}>0$, the current account moves into surplus following a shock, gradually returning to balance in the transition. If the economy is a net debtor, the increase in the return payable on foreign-currency denominated debt worsens the current account. For these reasons, the real exchange rate and the current account are positively cross-correlated under 
symmetric interest rate shocks.

\section{Caveats and conclusions}

Summarising our results, we find that in our simple two-country dynamic stochastic new open economy macroeconomics model the real exchange rate and the current account are not linked in a structural way. We analyse productivity, interest rate as well as preference shock and show that the correlation between the real exchange rate and the current account depends on the types of shocks hitting the economy, as well as a set of key structural parameters. In particular, we highlight the role of the steady-state net foreign asset position. In our model, shocks to the interest income from holding foreign assets have significant effects on the dynamics of the current account. In our simple model there is no a priori reason to assume that real exchange rate appreciations are caused, or indeed correlated with current account deficits or capital inflows. Future work could fruitfully test to what extent this result reflects the simplifications made here.

Indeed, the model presented here is highly stylised, as a result some of our simplifications could affect our results. Perhaps the most obvious feature missing from our model are investment dynamics. Woodford (2003) shows how to correctly incorporate capital accumulation in a model with Calvo pricing. Where as including capital accumulation is unlikely to significantly affect the dynamics of the real exchange rate, it most likely will have an effect on the dynamics of the current account, making the current account more countercyclical, as Backus, Kehoe and Kydland (1994) point out.

Another caveat concerns how we model deviations from PPP. In order to keep the model tractable, we have focussed only on local-currency-pricing as a source of real exchange rate 
deviations. This feature of our model causes the law of one price to fail. Engel (1999) shows that fluctuations in the law of one price account for most of the variability of the US real exchange rate. Modelling real exchange rate dynamics through changes in the relative price of non-traded goods, may result in different responses of the real exchange rate to productivity shocks. Specifically, if the intratemporal elasticity of substitution between home and foreign-produced traded goods is high, then a productivity shock to the traded goods sector can result in a real appreciation of the real exchange rate - via the BalassaSamuelson effect whereas such a shock results in a real depreciation in our model. How the Balassa-Samuleson effect would affect the current account is, however, not immediately obvious.

Another possible caveat concerns the way we model monetary policy. Sensitivity analysis, not reported here, has however found that changeing the weights on inflation and the output gap as well as the degree of interest rate smoothing in either or both of the countries does not change the qualitative results of this paper. 

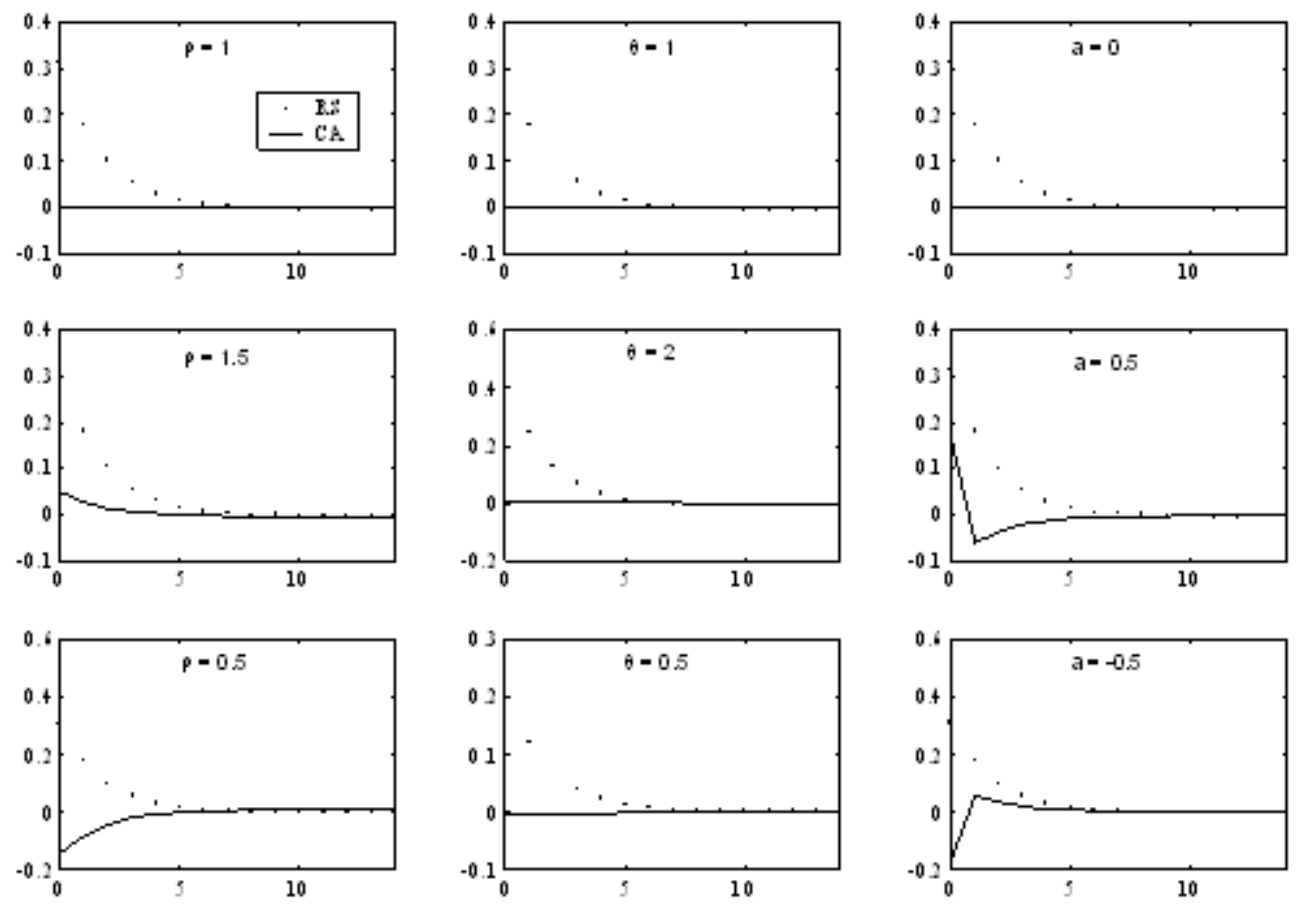

Figure 1: The real exchange rate and the current account following a 1 standard deviation shock to domestic total factor productivity for various parameters combinations. 

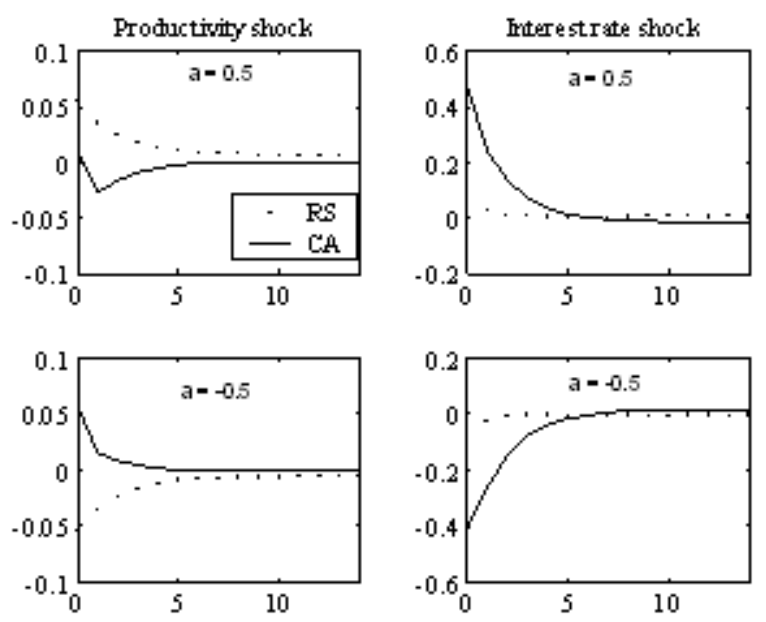

Figure 2: The real exchange rate and the current account following a symmetric 1 standard deviation shock to total factor productivity and interest rates for positive and negative net foreign assets.

\section{References}

Backus, D.K., Kehoe, P.J. and Kydland, F.,E. (1994). 'Dynamics of the trade balance and the terms of trade: The J-curve?', American Economic Review, vol. 84, no. 1 (March), pp. 84-103.

Backus, D.K., Kehoe, P.J. and Kydland, F.,E. (1995). 'International business cycles: Theory and evidence', in Thomas F. Cooley (ed.), Frontiers of Business Cycle Research, Princeton University Press, Princeton, pp. 331-56.

Bailey, A., Millard, S. and Wells, S. (2001). 'Capital flows and exchange rates', Bank of England Quarterly Bulletin, Autumn, pp. 310-8.

Benigno, G. (2001). 'Real exchange rate persistence and monetary policy rules', London School of Economics, Journal of Monetary Economics, forthcoming.

Benigno, G. and Thoenissen, C. (2003a). 'Equilibrium exchange rates and supply-side performance', Economic Journal, vol. 113, no. 486, pp 103-24.

Benigno, G. and Thoenissen, C. (2003b). 'On the consumption-real exchange rate anomaly', unpublished manuscript, LSE and University of St Andrews.

Benigno, P. (2001). 'Price stability with imperfect financial integration', CEPR Working Paper, No. 2854.

Bergin, P. (2002). 'How well can the new open economy macroeconomics explain the exchange rate and current account?', mimeo, UC Davis. 
Betts, C. and Devereux, M. (2000). 'Exchange rate dynamics in a model of pricing to market', Journal of International Economics, vol. 50, pp. 215-44.

Calvo, G. A. (1983). 'Staggered prices in a utility-maximising framework', Journal of Monetary Economics, Vol. 12, pp. 383-98.

Chari, V.V., Kehoe, P.J. and McGrattan. E.R., (2002). 'Can sticky price models generate volatile and persistent real exchange rates?', Review of Economic Studies, vol. 69(5), pp. 533-63.

Engel, C. (1999). 'Accounting for US real exchange rate changes', Journal of Political Economy, vol. 107, no. 3, pp. 507-38.

Fernandez-Corugedo, E.W. and Cromb, R (2002). 'Interest rates and consumption when there is no uncertainty', unpublished manuscript, Bank of England.

Heathcote, J. and Perri, F. (2002). 'Financial autarky and international business cycles', Journal of Monetary Economics, 49, pp. 601-27.

King, R. and Watson, M. (1998). 'The solution of singular linear difference systems under rational expectations', International Economic Review, Vol. 39, No 4, pp. 10151026.

Lane, P.R. (2001). 'The new open economy macroeconomics: a survey', Journal of International Economics, vol. 54(2), pp. 235-66.

Lane, P.R. (2001). 'Money shocks and the current account', in G. Calvo, R. Dornbusch and M. Obstfeld (eds.) Money, Factor Mobility and Trade: Essays in Honor of Robert Mundell. MIT Press, Cambridge, MA.

Lane, P.R. and Milesi-Ferretti, G.M. (2001) 'The external wealth of nations: measures of foreign assets and liabilities for industrial and developing countries', Journal of International Economics, vol. 55, pp. 263-94.

Lee, J. and Chinn M.D. (2002). 'Current account and real exchange rate dynamics in the G-7 countries', IMF Working Paper WP/02/130.

Obstfeld, M. and Rogoff, K. (1996). Foundations of International Macroeconomics. MIT Press, Cambridge, Massachusetts.

Rotemberg, J. J. and Woodford, M. (1997). 'An optimization-based econometric framework for the evaluation of monetary policy', in Bernanke, B S and Rotemberg, J J (eds), NBER Macroeconomic Annual 1997, MIT Press, Cambridge, MA.

Schmitt-Grohe, S. and Uribe, M. (2001). 'Closing small open economy models', Journal of International Economics, forthcoming.

Woodford, M. (2003). Interest and Prices: Foundations of a Theory of Monetary Policy. Chapter 5. Princeton University Press, Princeton. 